\title{
INVENTARISASI JENIS BULU BABI (Echinoedea) DI ZONA PASANG SURUT PANTAI DESA BUKAAN KECAMATAN LAKEA KABUPATEN BUOL
}

\author{
Suardi Laheng*, Andi Adli, Sri Devi \\ Program Studi Budidaya Perairan, Fakultas Perikanan, Universitas Madako \\ Jl. Kampus Umada, Kel. Tambun, Kec. Baolan, Kab. Tolitoli (94516). \\ *Email: suardiaseq@ gmail.com
}

\begin{abstract}
Abstrak
Penelitian ini bertujuan untuk mengetahui jenis bulu babi yang terdapat di zona pasang surut pantai Desa Bukaan Kecamatan Lakea Kabupaten Buol. Penelitian ini menggunakan tiga titik stasiun pengamatan yang masing-masing stasiun terdapat 3 transek line dan setiap transek terdapat 5 plot yang berukuran 1xl meter. Hasil penelitian menunjukkan terdapat tiga jenis bulu babi di zona pasang surut pantai Desa Bukaan yaitu Echinometra mathaei, Deadema setosum dan Stomopneustes variolaris.
\end{abstract}

Kata kunci : Inventarisasi, bulu babi, pasang surut

\section{PENDAHULUAN}

Negara kepulauan adalah ciri khas Indonesia dengan kekayaan sumberdaya alam yang tinggi. Keanekaragaman hayati yang melimpah akibat letak wilayah Indonesia berada pada Samudra hindia dan pasifik (Kottelat, $d k k ., 1993$ ). Kawasan pesisir memiliki berbagai ekosistem pendukung yang sangat beragam seperti ekosistem manggrove, terumbu karang, padang lamun. Fhilum Echinodermata merupakan salah satu hewan yang menyukai tempat tersebut. Hewan ini termasuk dalam golangan hewan invertebrata. Echinodermata berasal dari bahasa yunani Echinos yang berarti duri dan derma yang berarti kulit. Secara umum, Echinodermata yang berarti hewan yang memiliki kulit berduri atau berbintil (Jalaluddin dan Ardeslan, 2017). Salah satu jenis Echinodermata yang sering dijumpai di perairan yaitu bulu babi (Moningkey, dkk., 2010). Bulu babi memiliki ciri khusus yaitu terdapat duri-duri pada tubuhnya dan sering dijumpai pada daerah terumbu karang dan padang lamun (Wulandari, $d k k$., 2015). Hewan ini aktif dimalam hari untuk mencari makan (Zakaria, 2013). Penelitian yang telah dilakukan oleh Purnomo, $d k k$., (2019), diketahui bahwa di perairan Pulau Cilik, Kepulauan Karimunjawa ditemukan 4 jenis spesies bulu babi yaitu Diadema setosum, D. antillarum, D. savignyi and Echinothrix calamaris. Pantai tersebut memiliki substrak berpasir, pecahan karang, terumbu karang. Substrak tersebut menjadi salah satu faktor keberadaan dari spesies bulu babi. Indarjo $d k k$., (2004) menyatakan bahwa fungsi terumbu karang sebagai habitat berbagai spesies air laut misalnya Echinodermata, ikan karang dan kima.

Desa Bukaan merupakan salah satu desa yang berada pada Kabupaten Buol, Provinsi Sulawesi Tengah yang dilewati oleh garis pantai serta memiliki kawasan zona pasang surut yang berpotensi memiliki keragaman hayati yang tinggi. Hasil survey lapang dan informasi masyarakat setempat menunjukkan bahwa banyak ditemukan bulu babi dikawasan ini. Informasi mengenai spesies bulu babi (Echinoedea) yang hidup dipantai Desa Bukaan masih belum diketahui, maka perlu penelitian mengenai inventarisasi jenis bulu babi di zona pasang surut pantai desa Bukaan. Hal ini bertujuan untuk mengetahui bulu babi jenis apa saja yang terdapat di wilayah tersebut.

\section{METODE PENELITIAN}

\section{Alat dan Bahan}

Alat yang digunakan dalam penelitian ini yaitu $\mathrm{pH}$ meter air, thermometer, refraktometer, DO meter, balok kayu, meteran, tali, kamera, pipa (plot ukuran $1 \times 1 \mathrm{~m}^{2}$ ), toples. Bahan yang digunakan dalam penelitian ini yaitu alkohol $70 \%$ dan bulu babi.

\section{Lokasi Penelitian}

Lokasi penentuan stasiun berada di pantai Desa Bukaan, Kabupaten Buol, Sulawesi Tengah. Pengamatan bulu babi dilakukan pada 3 stasiun. Penentuan stasiun dilakukan secara Purposive sampling. Pengambilan data pada masing-masing stasiun menggunakan transek kuadrat dengan bantuan transek garis (Gambar 1). 


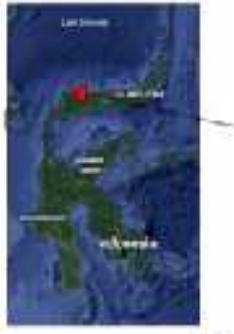

(A)

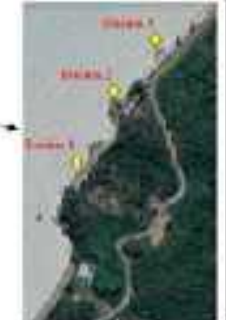

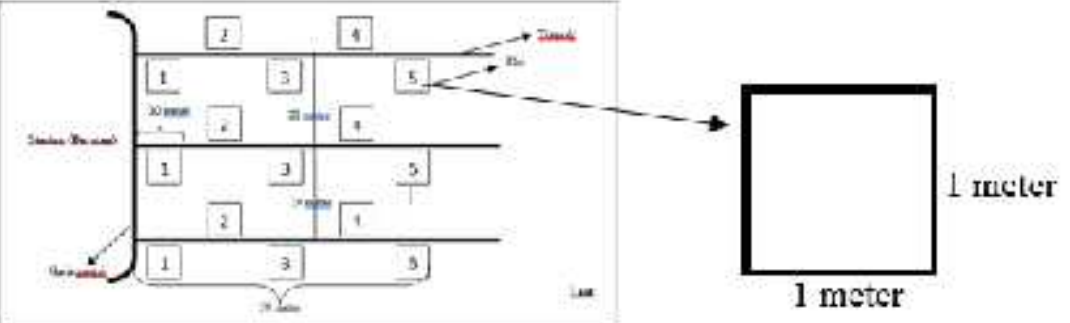

(B)

Gambar 1. (A) Lokasi pengamatan, (B) Teknik pengambilan data

Pengamatan bulu babi menggunakan 3 Stasiun. Setiap stasiun terdapat 3 transek garis sepanjang 50 meter mengarah ke pantai. Transek garis memiliki jarak 20 meter antar transek garis lainnya. Transek garis memiliki 5 plot ukuran 1 meter x 1 meter. Jarak plot satu dengan plot lainnya yaitu 10 meter (Purnomo et al., 2019).

\section{Pengambilan Data Bulu babi dan kondisi lingkungan}

Bulu babi yang diamati pada setiap plot dengan jarak 10 meter antar plot lainnya dalam setiap transek garis (Gambar 1). Spesies bulu babi yang terdapat dalam plot dicatat jenis dan jumlahnya. Selanjutnya bulu babi di dokumentasikan dan di awetkan menggunakan alcohol 70\% dalam toples. Bulu babi yang ditemukan di identifikasi menggunakan buku dan jurnal ilmiah.

Pengamatan kondisi lingkungan meliputi jenis substrak dan kualitas air. Pengamatan jenis substrak pada setiap stasiun di lakukan secara visualisasi sedangkan pengukuran kualitas air (suhu, salinitas, oksigen terlarut, $\mathrm{pH}$ ) dilakukan dengan cara insitu yaitu mengambil dan mengukur secara langsung contoh air pada masing-masing stasiun pengamatan.

\section{Parameter Uji}

\section{Kelimpahan Individu Bulu Babi}

Kelimpahan individu dihitung menggunakan rumus (Brower dan Zar, 1997) yaitu:

$$
K I=\frac{\pi i}{A}
$$

$\mathrm{Ki}$ adalah kelimpahan individu, (individu $/ \mathrm{m}^{2}$ ), ni adalah jumlah tiap jenis (individu), A adalah luasan transek $\left(\mathrm{m}^{2}\right)$.

\section{Kelimpahan relatif}

Kelimpahan relatif individu bulu babi didefinisikan sebagai persentase dari jumlah suatu individu terhadap jumlah total individu yang terdapat di daerah tertentu, dihitung menggunakan rumus (Michael, 1994) yaitu:

$$
K R=\frac{n \dot{i}}{N} \times 100 \%
$$

Dimana KR adalah kelimpahan relatif, ni adalah jumlah individu jenis, $\mathrm{N}$ adalah jumlah total individu.

\section{Indeks Keanekaragaman}

Perhitungan Keanekaragaman jenis ini dilakukan dengan menggunakan Indeks Keanekaragaman Shannon-Wienner yang didasarkan pada logaritma basis dua (Odum,1971) .

Keterangan :

$$
H^{\prime}=-\sum P i(L N P i)
$$

$H^{\prime} \quad$ : Indeks keanekaragaman Shannon-Wienner /

$\mathrm{Pi} \quad:$ ni $/ \mathrm{N}=$ proporsi jenis ke $-\mathrm{i}$ terhadap jumlah total

Dengan kriteria :

$$
\begin{array}{ll}
H^{\prime}<1 & =\text { Keanekaragaman jenis rendah } \\
1 \leq H^{\prime} \leq 3 & =\text { Keanekaragaman jenis sedang } \\
H^{\prime}>3 & =\text { Keanekaragaman jenis tinggi }
\end{array}
$$




\section{Indeks Dominansi}

Nilai indeks dominansi digunakan untuk menggambarkan ada tidaknya dominasi suatu jenis dalam suatu komunitas, yang dihitung dengan menggunakan indeks dominansi Simpson (Magurran, 1988).

Dengan kriteria :

$$
C=\sum P i^{2}
$$

$0,00<\mathrm{C} \leq 0,50=$ Dominansi rendah

$0,50<\mathrm{C} \leq 0,75=$ Dominansi sedang

$0,75<\mathrm{C} \leq 1,00=$ Dominansi tinggi

\section{Analisis Data}

Data yang diperoleh dari hasil penelitian di analisis secara kualitatif yaitu secara deskriptif yang disajikan dalam bentuk gambar dan tabel. Penentuan komposisi jenis bulu babi dilakukan dengan cara identifikasi menggunakan buku identifikasi dan jurnal ilmiah melalui karakter marfologi.

\section{HASIL DAN PEMBAHASAN}

Berdasarkan penelitian yang dilakukan di Desa Bukaan Kecamatan Lakea Kabupaten Buol ditemukannya 3 spesies bulu babi yaitu Echinometra mathaei, Diadema setosum dan Stomopneuste variolaris (Gambar 2). Kelimpahan individu dan kelimpahan relatif terlihat pada Gambar 3 dan Gambar 4.

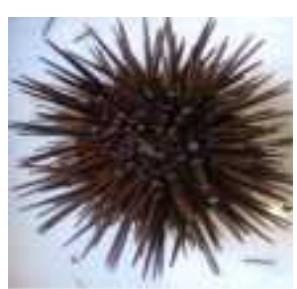

(A)

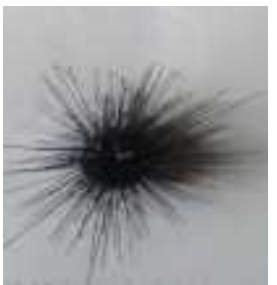

(B)

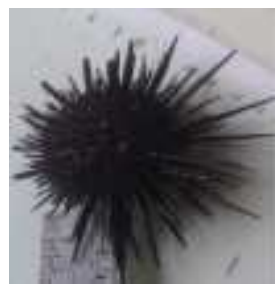

(C)

Gambar 2. (A) E. mathaei, (B) D. setosum, (C) S. variolaris

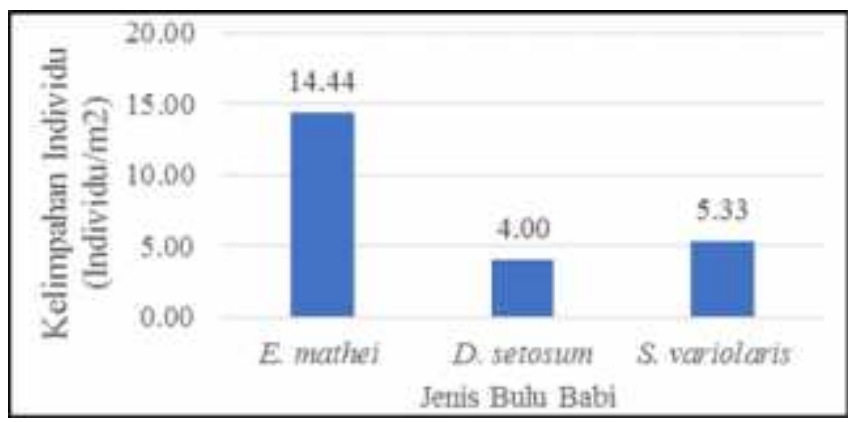

Gambar 3. Kelimpahan Individu Bulu Babi

Kelimpahan individu spesies bulu babi yang tertinggi yaitu E. mathaei sebesar 14,44 individu $/ \mathrm{m}^{2}$ yang tergolong kedalam kategori sangat berlimpah dan pada jenis $S$. variolaris sebesar 5,33 individu $/ \mathrm{m}^{2}$ sedangkan kelimpahan terendah diperairan desa bukaan yaitu jenis $D$. setosum sebesar 4 individu $/ \mathrm{m}^{2}$ yang tergolong kategori kurang berlimpah. 


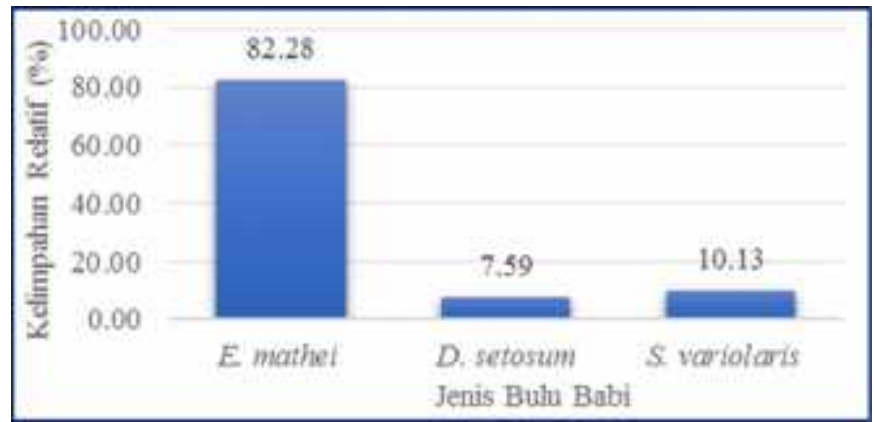

Gambar 4. Kelimpahan relatif bulu babi

Berdasarkan hasil penelitian yang dilakukan dipantai Desa Bukaan Kecamatan Lakea Kabupaten Buol menunjukkan spesies E. mathaei merupakan kelimpahan relatif paling tinggi ditemukan dengan jumlah $82.28 \%$ dan jenis $S$. variolaris dengan jumlah $10,13 \%$ sedangkan jenis D. sitosum merupakan jenis yang paling sedikit ditemukan dengan jumlah 7,59\%.

Kelimpahan kelimpahan individu dan kelimpahan relatif yang tinggi pada spesies bulu babi jenis E. mathaei diduga karena kondisi perairan yang ada di pantai Desa Bukaan yang mendukung kehidupan bulu babi jenis ini. Selain itu, substrat yang terdapat diperairan tersebut didominasi oleh terumbu karang yang sesuai untuk kehidupan bulu babi jenis ini. Hal ini sejalan dengan Miala $d k k$., (2015), yang menyatakan bahwa bulu babi jenis E. mathaei adalah salah satu jenis bulu babi yang hanya dijumpai di celah-celah bebatuan atau pecahan karang. Berbeda dengan jenis dari $D$. setosum yang dapat ditemukan pada hampir semua daerah mulai dari rataan pasir, padang lamun, rataan karang dan tubir, hingga ke daerah bebatuan. Namun keberadaan jenis D. setosum diperairan pantai Bukaan tidak begitu melimpah hal ini diduga karena keberadaan lamun di pantai Bukaan tidak melimpah secara merata.

Ketiga jenis bulu babi yang ditemukan di Desa Bukaan memiliki ciri-ciri yang berbeda yaitu E. mathaei merupakan jenis bulu babi yang termasuk dalam kategori pencil urcin yang berarti bulu babi pensil. Hal ini dikarenakan bulu babi jenis ini memiliki duri yang berbentuk pensil dan sangat menyukai substrak berkarang pada perairan yang dangkal (Alwi dkk., 2020). E. mathaei memiliki warna hitam, merah muda, coklat, putih serta warna hijau. Panjang duri bulu babi jenis ini yaitu 10,85-40,26 mm (Moningkey, 2010).

D. setosum memiliki tubuh yang berbentuk bundar pentagonal dan pipih. Jenis ini memiliki warna yang khas yaitu berwana hitam dan memiliki duri yang cukup meruncing namun bagian duri dari bulu babi jenis ini sangat rapuh. Panjang duri $D$. setosum melebihi ukuran tubuhnya dan memiliki duri berukuran pendek berfungsi sebagai penggerak (Suryanti et,al. 2020). Alwi, dkk., (2020), menambahkan bulu babi jenis $D$. setosum memiliki warna hitam pekat dan memiliki bentuk tubuh seperti bola serta cangkang yang keras dan dikelilingi oleh duri yang memanjang keatas yang berfungsi sebagai salah satu cara untuk melindungi diri dari serangan predator, sedangkan mulut dari hewan ini terletak dibagian bawah cangkang dan anus yang terletak dibagian atas cangkangnya. Hewan ini memiliki 5 titik yang berwarna putih dimana pada setiap segmen terdapat satu titik putih hewan ini biasa hidup ditempat disubstrak berkarang, berpasir, terdapat alga atau lamun.

S. variolaris memiliki ciri-ciri tubuh berbentuk oval dan berwarna hitam kecoklatan ukuran tubuh berkisar antara 50-62 mm serta memiliki duri yang berdiri tegak dan tumpul, sedangkan permukaan durinya kasar, spesies ini memiliki ciri khas yaitu jika terpapar sinar matahari akan terlihat berwana hijau dan memiliki duri primer yang berkisar antara $20-40 \mathrm{~mm}$, duri sekunder berkisar antara 2-4 mm. Hidup pada substrak berpasir dan terdapat karang mati serta ditumbuhi lamun atau makroalga lainnya (Suryanti, $d k k ., 2020$ ).

Keanekaragaman adalah perbedaan yang dapat ditemukan pada komunitas atau kelompok berbagai spesies yang hidup di suatu tempat (Purnomo, $d k k$., 2019),. Nilai indeks keanekaragaman, di Perairan Pantai Desa Bukaan, Kabupaten Buol menunjukkan bahwa keanekaragaman termasuk dalam kategori sedang dengan nilai 2,49. Menurut Odum,1971, indeks keanekaragaman Bulu babi akan tergolong dalam kategori rendah apabila berada pada kisaran angka kurang dari 1 dan termasuk dalam kategori sedang apabila berkisar pada angka 1 sampai 3, dan dikatakan tinggi apa 
bila mencapai nilai 3 atau lebih. Keanekaragaman yang sedang pada jenis bulu babi diduga vegetasi lamun pantai Desa Bukaan tidak merata. Hal ini terlihat pada lokasi penelitian pada hanya stasiun 1 yang ditumbuhi padang lamun, stasiun 3 hanya ditemukan dalam jumlah sedikit sedangkan pada stasiun 2 tidak ditumbuhi padang lamun. Hal ini sejalan dengan penelitian yang dilakukan oleh Sadam, $d k k$., (2019), bahwa bulu babi dengan kelimpahan yang tinggi terdapat pada lokasi yang memiliki substrak pasir kasar serta ditumbuhi banyak lamun. Hal tersebut disebabkan bulu babi memanfaatkan padang lamun sebagai tempat untuk mencari makan, memijah dan juga sebagai salah satu tempat untuk berlindung diri dari serang predator.

Berdasarkan hasil penelitian yang ditemukan diperairan pantai Desa Bukaan, Kabupaten Buol ditemukan hasil dominansi dengan kisaran nilai sebesar 0.09. Kategori tersebut secara umum menunjukkan bahwa komposisi bulu babi Pantai Desa Bukaan tidak memperlihatkan adanya dominasi pada spesies tertentu. Indeks dominansi dikategorikan rendah karena pada kisaran angka $\leq 0,50$ dan dikategorikan sedang apabila berada pada kisaran angka $\leq 0,75$, dan dikatakan tinggi apabila mencapai angka 1 (Magurran, 1988). Dominansi yang rendah juga diperlihatkan pada penelitian yang dilakukan oleh Alwi $d k k$., (2020), yang mana pada hasil analisis indeks dominasi bulu babi dilokasi penelitian dinyatakan tidak ada spesies yang mendominasi karena nilai rata-rata dari yang didapat pada tiga stasiun hanya sebesar 0,396 . Hal ini dikarenakan penyebaran pada bulu babi disetiap lokasi ini tidak menyebar secara merata diseluruh perairan sehingga tidak terdapat dominansi tertentu pada setiap jenis. Selain itu juga tingginya nilai kemerataan bulu babi dilokasi penelitian menunjukan bahwa tidak ada persaingan yang berarti antara spesies dalam hal ruang maupun makanan.

Kualitas air di zona pasang surut pantai Desa Bukaan yaitu suhu berkisar $31-38^{\circ} \mathrm{C}$. Suryanti $d k k$., (2014) mengemukakan bahwa kedaan perairan dengan kisaran suhu berada pada $29-31^{\circ} \mathrm{C}$ merupakan kisaran yang baik untuk kelangsungan hidup bulu babi namun meskipun demikian hewan ini masih mampu bertahan hidup pada kisaran suhu $36-40^{\circ} \mathrm{C}$. Nilai oksigen terlarut (DO) yaitu 8,3 ppm. Yundha $d k k$., (2017), menyatakan oksigen terlarut 7,4-8,3 ppm merupakan kisaran angka yang dianggap masih dalam kisaran yang baik untuk kehidupan Echinodermata. Nilai pH yaitu berkisar 8,1-8,4. Nilai $\mathrm{pH}$ tersebut masih dalam kategori baik untuk pertumbuhan dan kelangsungan kehidupan bulu babi (Alwi $d k k$., 2020; Sadam $d k k$., 2019). Nilai Salinitas yaitu 3640 PPT. Menurut Suryanti $d k k$., (2020). Salinitas perairan yang berada pada kisaran angka 30-40 PPT masih optimal bagi spesies bulu babi.

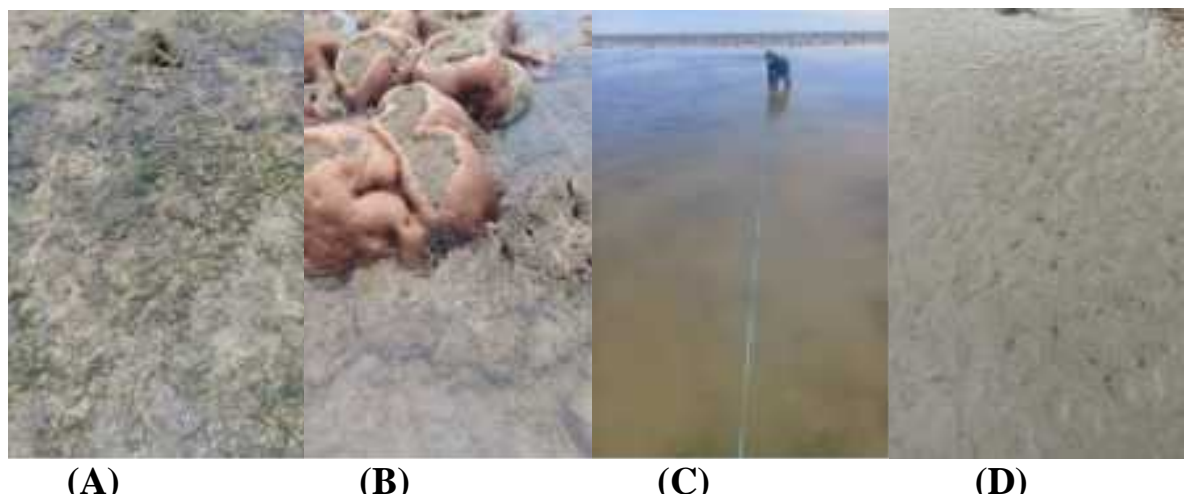
(A)
(B)

(C)

(D)

Gambar 5. (A) Substrat berlamun, (B) Substrat karang, (C) Substrat pasir berlumpur, (D) Substrat pasir.

Perairan Desa Bukaan pada Stasiun I memiliki substrak berpasir, berkarang, berlamun serta ditemukan 74 individu bulu babi. Stasiun II memiliki substrat pasir berlumpur, berkarang serta ditemukan 28 individu bulu babi. Stasiun III memiliki substrat berpasir, berkarang dan ditumbuhi sedikit berlamun serta ditemukn 56 individu bulu babi (Gambar 5). Menurut Yudasmara (2013), keberagaman pada substrak yang ada di suatu lokasi akan mempengaruhi keberagaman dari bulu babi yang ada ditempat tersebut. Seperti pantai zona pasir, zona pertumbuhan lamun dan rumput laut, zona terumbu karang dan zona tubir dan lereng terumbu, akan menghasilkan jenis dan 
kelimpahan yang berbeda. Hal ini menunjukkan bahwa semakin beragam tipe substrat pada suatu perairan maka semakin beragam pula jenis bulu babi yang ditemukan.

\section{KESIMPULAN}

Bulu babi yang ditemukan di zona pasang surut pantai Desa Bukaan Kecamatan Lakea Kabupaten Buol yaitu 3 spesies yaitu jenis Echinometra mathaei, Deadema setosum, Stomopneustes variolaris.

\section{DAFTAR PUSTAKA}

Alwi, D., Muhammad S., Tae I., 2020. Karakteristik Morfologi dan Indeks Ekologi Bulu Babi (Echinoidea) di Perairan Desa Wawama Kabupaten Pulau Morotai. Jurnal Sumberdaya Akuatik Indopasifik. 4(1), 23-32

Brower, J. E., Zar, J. H., 1997. Field and Laboratory Method for General Ecology. Lowa : Brown

Kottelat M , Anthony J. W, Sri Nurani K., Soetikno W., 1993. Freshwater Fishes of Western Indonesia and Sulawesi. Jakarta : Periplus Editios (HK)

Magurran, A. E., 1988. Ecological Diversity and Its Measurement. Chapman and. Hall: USA

Michael, P. (1994). Metoda Ekologi untuk Penyelidikan Lapangan dan Laboratorium. UI Press, Jakarta.

Moningkey, R. D., 2010. Pertumbuhan Populasi Bulu Babi (Echinometra mathaei) Di Perairan Pesisir Kima Bajo Kabupaten Minahasa Utara. Jurnal Perikanan dan Kelautan Tropis. 6(2), 73-78.

Indarjo, A., Wijadmoko, W., M. Munasik., 2004. Kondisi Terumbu Karang di Perairan Pulau Panjang Jepara. Jurnal Ilmu Kelautan. 9(4), 217-224

Jalaluddin, J., dan Ardeslan, A. (2017). Identifikasi Dan Klasifikasi Phylum Echinodermata Di Perairan Laut Desa Sembilan Kecamatan Simeulue Barat Kabupaten Simeulue. Jurnal Biology Education, 6(2).

Miala, I., Pratomo, A., dan Irawan, H., (2015). Hubungan Antara Bulu Babi, Makroalgae Dan Karang Di Perairan Daerah Pulau Pucung. Repository Umrah.

Odum, E. P., 1993. Dasar-dasar Ekologi. Diterjemahkan dari Fundamental of Ecology oleh PT. Samingan. Gadjah Mada University Press. Yogyakarta.

Suryanti, S., Fatimah, P. N. P. N., Rudiyanti, S., (2020). Morfologi, Anatomi dan Indeks Ekologi Bulu Babi di Pantai Sepanjang, Kabupaten Gunungkidul, Yogyakarta. Buletin Oseanografi Marina, 9(2), 93-103.

Supono, A. U., (2010). Struktur komunitas ekinodermata di padang lamun Perairan Kema, Sulawesi Utara. Oseanologi dan Limnologi Indonesia, 36(3), 329-341.

Sadam. L, D., Emiyarti., Ira., (2019). Keanekaragaman Bulu Babi (Echinoidea) Pada Kawasan Lamun Di Perairan Desa Langara, Kecamatan Wawonii Barat Kabupaten Konawe Kepulauan. Jurnal Sapa Laut, 4(3), 113-122

Purnomo I G P, Dharma I G B S, Putra I N G. 2019. Struktur Komunitas dan Sebaran Bulu Babi (Echinoidea) di Kawasan Padang Lamun Pantai Serangan, Bali. Journal Of Marine Research And Technology, 2(2), 29-33

Wulandewi, N. L. E., Subagio, J. N. J. N., Wiryatno, J. (2015). Jenis dan Densitas Bulu Babi (Echinoidea) Di Kawasan Pantai Sanur dan Serangan Denpasar-Bali. Jurnal Simbiosis, 3(1), 269-280

Yudasmara, G. A., (2013). Keanekaragaman Dan Dominansi Komunitas Bulu Babi (Echinoidea) Di Perairan Pulau Menjangan Kawasan Taman Nasional Bali Barat. Jurnal Sains dan Teknologi, 2(2), 213-220

Simatupang, M. Y. C., Sarong, M. A., Ulfah, M. (2017). Keanekaragaman Echinodermata Dan Kondisi Lingkungan Perairan Dangkal Pulau Pandang Kabupaten Batu Bara Provinsi Sumatera Utara. Jurnal Ilmiah Mahasiswa Kelautan Perikanan Unsyiah, 2(1), 97-103

Zakaria, I. J. (2013). Komunitas Bulu Babi (Echonoidea) di Pulau Cingkuak, Pulau Sikuai dan Pulau Setan Sumatera Barat. Prosiding Semirata 2013, 1(1), 381-387 